Romanticism on the Net

An open access journal devoted to British Romantic literature

Ron Romanticism on the Net

\title{
Poetic Industry and Abominable Superstition: Southey on Lope de Vega
}

\section{Jonathan González}

Numéro 68-69, spring-fall 2017

Robert Southey

URI : https://id.erudit.org/iderudit/1070620ar

DOI : https://doi.org/10.7202/1070620ar

Aller au sommaire du numéro

\section{Éditeur(s)}

Université de Montréal

\section{ISSN}

2563-2582 (numérique)

Découvrir la revue

\section{Citer cet article}

González, J. (2017). Poetic Industry and Abominable Superstition: Southey on Lope de Vega. Romanticism on the Net, (68-69).

https://doi.org/10.7202/1070620ar

\section{Résumé de l'article}

In the second edition of Joan of Arc (1798) and in Roderick, The Last of the Goths (1814), Robert Southey included explanatory notes that featured excerpts from Lope de Vega's Jerusalén conquistada (1609), an epic poem in twenty cantos based on Torquato Tasso's Gerusalemme liberata (1581) and built around a mythified account of the Third Crusade. This article argues that, rather than being offhand allusions, those references lie at the core of a deeper literary, religious, and political interest in the figure and writings of the sixteenth-century Spanish writer. Southey's contribution to the criticism of the so-called "Phoenix of Wits" might be difficult to assess, not least because in a period of over twenty years he went from asserting that "Lope de Vega is never sublime, seldom pathetic, and seldom natural" (CLRS 188) in a series of public letters he contributed to the Monthly Magazine in 1796, to becoming a true aficionado of this "prodigy of nature," in 1818 celebrating his Rimas sacras (1599) as being characterised by "strains of sober piety and elevated devotion, in which a true Christian might devoutly join, and bless the man who has expressed for him so well the aspirations of hope and faith" ( $Q R$ 45). Southey's ambivalent cultural cosmopolitanism, nevertheless, meant that even when he celebrated Lope de Vega's poetic industry, he was balanced in his praise, leaving room for harsh attacks on the "audacious instances of Romish impiety and imposture" in the Spaniard's oeuvre ( $Q R$ 44). Southey's ambivalence towards Lope de Vega is read here in the light of his investments in all things Spanish, considering the public and private, domestic and international dimensions of his writings, and arguing that his fixation with Lope de Vega epitomises what Lynda Pratt (Contexts xxvi) has defined as the Southeyan preoccupation with a foreign "Other" that is both fascinating and repulsive.
Ce document est protégé par la loi sur le droit d'auteur. L'utilisation des services d'Érudit (y compris la reproduction) est assujettie à sa politique d'utilisation que vous pouvez consulter en ligne.

https://apropos.erudit.org/fr/usagers/politique-dutilisation/ 
Romanticism on the Net \#68-69 (Spring-Fall 2017). Special issue on Robert Southey. Guest-edited by Tim Fulford (De Montfort University) and Matthew Sangster (University of Glasgow)

\title{
Ron \\ Romanticism on the Net
}

\section{Poetic Industry and Abominable Superstition: Southey on Lope de Vega}

Jonathan González

University of La Rioja

\begin{abstract}
In the second edition of Joan of Arc (1798) and in Roderick, The Last of the Goths (1814), Robert Southey included explanatory notes that featured excerpts from Lope de Vega's Jerusalén conquistada (1609), an epic poem in twenty cantos based on Torquato Tasso's Gerusalemme liberata (1581) and built around a mythified account of the Third Crusade. This article argues that, rather than being offhand allusions, those references lie at the core of a deeper literary, religious, and political interest in the figure and writings of the sixteenth-century Spanish writer. Southey's contribution to the criticism of the so-called "Phoenix of Wits" might be difficult to assess, not least because in a period of over twenty years he went from asserting that "Lope de Vega is never sublime, seldom pathetic, and seldom natural" (CLRS 188) in a series of public letters he contributed to the Monthly Magazine in 1796, to becoming a true aficionado of this "prodigy of nature," in 1818 celebrating his Rimas sacras (1599) as being characterised by "strains of sober piety and elevated devotion, in which a true Christian might devoutly join, and bless the man who has expressed for him so well the aspirations of hope and faith" ( $Q R$ 45). Southey's ambivalent cultural cosmopolitanism, nevertheless, meant that even when he celebrated Lope de Vega's poetic industry, he was balanced in his praise, leaving room for harsh attacks on the "audacious instances of Romish impiety and imposture" in the Spaniard's oeuvre ( $Q R 44)$. Southey's ambivalence towards Lope de Vega is read here in the light of his investments in all things Spanish, considering the public and private, domestic and international dimensions of his writings, and arguing that his fixation with Lope de Vega epitomises what Lynda Pratt (Contexts xxvi) has defined as the Southeyan preoccupation with a foreign "Other" that is both fascinating and repulsive. ${ }^{1}$
\end{abstract}

\section{Biographical Note}

Jonathan González is a PhD candidate at the University of La Rioja writing his thesis on the Romantic period's cult of posterity and the textual afterlives of William Wordsworth in continental Europe. He is a regular reviewer for Romanticism and has written articles on Wordsworth, Southey, Coleridge, and Romantic pedestrianism for several Spanish and English journals, including Odisea: Journal of English Studies and The Coleridge Bulletin. Together with Cristina Flores and Tim Fulford, he is currently working on a scholarly edition of Southey's 1797 travelogue Letters Written During a Short Residence in Spain and Portugal, under contract with Routledge. 


\section{Romanticism on the Net \#68-69 (Spring-Fall 2017). Special issue on Robert Southey. Guest-edited by Tim Fulford (De Montfort University) and Matthew Sangster (University of Glasgow)}

1. In the first edition of Letters Written During a Short Residence in Spain and Portugal (1797), Southey — who would grow to become one of the leading Hispanists of late Georgian Englandcontended that "the dangerous abilities of Lope de Vega assisted the progress of the evil" (LSaP 127), arguing that the wickedness that took possession of Spanish and Portuguese literature in general, and Lope's poetry in particular, was enhanced by the double despotism of the Catholic Church and Iberian politics. He noted that the Spaniard, "this prodigy of nature," "wrote for the multitude, and cared not for the critics," arguing that those works that testified to his poetic genius were but strokes of good luck resulting from his exceptional productivity, for "strange indeed would it have been if the man who constantly wrote five sheets a day, did not in the rabble of his thoughts stumble upon some that were good." He thereby concluded that "the wit and Satire of Villegas and Cervantes were wasted against this careless yet lively versifier" ( $L S a P 127)$.

2. By late 1817 and early 1818 , Southey was an experienced student of Spanish literature, having produced an extensive body of Spanish texts, including translations of Amadis of Gaul (1803) and the Chronicle of the Cid (1808), as well as his Roderick, The Last of the Goths (1814) (publications that had led to his appointment as a Fellow of both the Royal Spanish Academy and Royal Spanish Academy of History). ${ }^{2}$ Lope de Vega now seemed to him far from a mediocre writer, one who no longer epitomised the evils of Spanish Popery and politics - at least not entirely. Southey's mature view is set out in his letter to John May of September 4, 1817, wherein he "heartily wish[ed] that I had the collected edition of Lope de Vega,-I have a good many of his works separately, in the original editions,- - but it would be much more satisfactory to possess the whole" (CLRS 3021). That same month, he told his uncle Herbert Hill of the delight he took from finally bringing himself to read Lope's Arcadia (1598), "which I had not patience to do twenty years ago" (CLRS 3027). Southey's interest reached its peak in 1818, when his forty-sixpage-long article for the Quarterly Review on the second edition of Lord Holland's Some Account of the Life and Writings of Lope Felix de Vega Carpio $(1806,1817)$ finally saw the light. ${ }^{3}$ Southey had written a shorter notice of the first edition for the Annual Review in 1807, where he put forward some of his own translations of Lope against Lord Holland's, arguing that some of the 


\section{Romanticism on the Net \#68-69 (Spring-Fall 2017). Special issue on Robert Southey. Guest-edited by Tim Fulford (De Montfort University) and Matthew Sangster (University of Glasgow)}

pieces he rendered into English were "so much prettier in the original, that if Spanish were as commonly read as French" he would have made "no attempt ... at versifying [them]" (AR 399).

3. Lope de Vega could be said to be the foremost figure of Spanish letters after Miguel de Cervantes, who actually dubbed the former a "monstruo de la naturaleza" [great prodigy of nature] who "alzóse con la monarquía cómica" [raised himself to the throne of theatre] (93). A sixteenthcentury multifaceted playwright, poet, and novelist, also labelled the "Phoenix of Wits" or the "Phoenix of Spain," Lope is said to have had a literary output unique in the history of world literature. According to Alexander Samson and Jonathan Thacker, "his popular renown stems in roughly equal measure from his exceptional productivity and his eventful life," the "Lope myth" "present[ing] the man as a flawed character possessed of a unique genius" (4). His major literary contribution was his body of plays which, as he explained in his verse essay Arte nuevo de hacer comedias [The New Art of Writing Plays], combined comedy with tragedy, entertainment with moral purpose, allowed characters to speak in a style in accordance with their social status, and, more importantly, did away with the classical unities of action, time and place.

4. Southey studied many of the Spaniard's plays in depth, most notably La estrella de Sevilla [The Star of Seville] (1623) (AR 409-411). He took Lope's tragedy El último godo [The Last of the Goths] (1617) as a source for his own Roderick, The Last of the Goths, the epic in which he "used the eighth-century conflict for control of Spain to allegorize the Peninsular War between Napoleonic France and the allied forces of the Spanish resistance and of Britain" (Fulford, Coteries 99). ${ }^{5}$ Allusions to the Spaniard are found in Southey's private correspondence as early as 1793. These originally revolve around the public image of Lope as a unique, superhuman genius whose vast productivity granted him a myth-like status, an image that has proved to be immune to the ravages of time in assessments of his life and work ever since the sixteenth century (Thacker 23). These references should not be easily dismissed as impromptu allusions, as the young Southey boasted in 1793 of his having written "more than any author ever did at my age," with the idea that, in a very few years, he would "out volume Lope de Vega" (CLRS 71). Southey might have seen something of himself in the Spaniard, or rather something that he desired and 


\section{Romanticism on the Net \#68-69 (Spring-Fall 2017). Special issue on Robert Southey. Guest-edited by Tim Fulford (De Montfort University) and Matthew Sangster (University of Glasgow)}

would long for until his death in 1843 - this was a point he would keep highlighting in letters to friends and relatives over the years (e.g. CLRS 336, 386). Southey's longing for literary posterity, together with the Byronic idea of his being an "entire man of letters," "someone who carefully allotted a portion of every day to a different writerly task and who always accomplished precisely what he set out to do" (Pratt, Romanticism 1), bears an uncanny resemblance to the myth of Lope's productivity, while actually hiding a similar and complex figure to that of the Phoenix, one of "a writer who was a great projector and planner but who did not always succeed in realising his ideas and ambitions" (1).

5. Nevertheless, it was not until Southey first set foot on Spanish soil as part of his visit to the Iberian Peninsula in 1795-96 that, as he would later acknowledge in Letters from Spain and Portugal, "long acquainted with the name of Lope de Vega ...I eagerly made acquaintance with him as soon as it was in my power" (LSaP 119). Prior to 1795, Southey had only known Lope by reputation, and it seems as if he must have tried to get hold of his writings immediately after landing in northern Spain. In a letter to Grosvenor Bedford, begun in December 1795 and sent in February 1796, only two months after his arrival, Southey proudly declared that "I read the two languages with facility, \& am now abridging the Angelica of Lope de Vega" (CLRS 45). He kept working on Lope and Spanish literature after his return to British soil in May 1796. In July, the first of a series of articles that he wrote for the Monthly Magazine under the pen name "T. Y." appeared, ${ }^{6}$ intended to "give some account of the best Spanish and Portuguese poets, to analyze the plans of their most esteemed works, and translate such specimens as, while they are brief enough to suit your Magazine, may give some idea of the genius, taste, and manner of the authors" (CLRS 164). An article devoted entirely to Lope de Vega appeared in the December 1796 issue, where Southey offered a comprehensive overview of his poetical works and included some translations so as to illustrate how "purity of language and harmonious versification distinguish all the poems of this indefatigable Spaniard" (CLRS 188). At the same time as Southey praised Lope's poetic genius, he was also critical of him, declaring that he was "never sublime, seldom pathetic, and seldom natural; rarely above mediocrity in any of his writings, he has attained to celebrity by their number" (CLRS 188). Southey adopts a deeply ambiguous stance here, celebrating and condemning the Spaniard at once - a stance that owed much to his complex 


\section{Romanticism on the Net \#68-69 (Spring-Fall 2017). Special issue on Robert Southey. Guest-edited by Tim Fulford (De Montfort University) and Matthew Sangster (University of Glasgow)}

fascination with and antipathy to Catholicism. As Tom Duggett (2012) has shown, the antiCatholic terms of Southey's conservatism were a prominent feature in most of the writings he produced throughout the 1800 s and early 1810s, precisely coinciding with the period of his extensive readings of Lope. Beginning in 1796, Southey centred his attacks on compositions that either had strong Catholic contents - these "prostitute[d] poetry" to superstitious religion (CLRS 188) _ or that were clearly anti-English, including La dragontea (1598), a poem that portrayed Francis Drake as a ruthless pirate rather than as an English hero. Southey "found no inducement to see Sir Francis Drake butchered with such clumsy barbarity” (LSaP 166).

6. The initial stages of Southey's poetics of ambivalence towards Lope were also marked by the fact that in 1796, despite his proudly declaring that "I have read nearly two hundred of his sonnets" (CLRS 188), he was only acquainted with a small part of Lope's vast production. For quite some time, Southey relied heavily on secondary sources for his opinions on those poems of Lope he had not had access to. A case in point is his drawing from William Hayley's An Essay on Epic Poetry (1782), where Lope's Jerusalén conquistada [Jerusalem Conquered] (1609), an epic poem in twenty cantos based on Torquato Tasso's Gerusalemme liberata [Jerusalem Delivered] (1581), is heavily condemned and readily dismissed as utterly inferior in every way to Tasso's, to the point that Hayley declines "to swell these extensive notes by an enlarged description of so unsuccessful a work" (206). Along these lines, Southey declared in one of his pieces for the Monthly Magazine how, of the longer poems of the Spaniard,

I have never seen the Jerusalen Conquistada: I am, however, well enough acquainted with the style and powers of Lope de Vega, fully to credit Mr. Hayley, when he says, that it is, in every respect, infinitely inferior to the work of Tasso. (CLRS 188)

Despite accepting Hayley's views in 1796, only two years later, in January 1798, after actually having read Jerusalén, Southey was to proclaim it Lope's "most famous, \& indeed best, poem," also declaring a study of this epic piece was occupying his whole attention: "it is in 20 huge books-but I see land" (CLRS 285). Although he originally worked with a 1620 copy of Jerusalén conquistada held at Dr. Williams's Library in New Cross Street (CLRS 285, 1214; Cogan I 344), his developing fascination eventually lead Southey to acquire a very scarce first edition with woodcut portraits, which he would retain until the end of his life. ${ }^{8}$ Together with Dr. 


\section{Romanticism on the Net \#68-69 (Spring-Fall 2017). Special issue on Robert Southey. Guest-edited by Tim Fulford (De Montfort University) and Matthew Sangster (University of Glasgow)}

Williams's Library and his own book collecting ventures, Southey's private correspondence evidences how Holland House Library also furnished him with the materials he needed throughout his career to proceed with his readings and study of Lope de Vega (CLRS 1390, 1426, 1795, 2309, 3566, 3764). ${ }^{9}$ The long-standing fascination Southey developed for Jerusalén is evidenced in his notes to the second edition of Joan of Arc, as well in those to Roderick, where he both pointed readers to and featured extensive fragments from what he came to regard as Lope's magnum opus.

7. In Roderick, Southey embedded six notes throughout the poem that included extensive excerpts in Spanish from those parts of Jerusalén he had used to shape and articulate his own epic. This influence extended as far as the closing lines of the poem, "A humble tomb was found, which bore inscribed / In ancient characters King Roderick's name” ( $L P W$ II 203), from which Southey pointed his readers to a Latin epitaph Lope had turned "into two stanzas of Latin rhymes, which occur in the midst of one of his long poems" (LPW II 312). ${ }^{10}$ The impact of Jerusalén upon the second edition of Joan of Arc is equally significant, considering that in the first edition from 1796 there are no references to Lope's poem. Once he had a chance to read Jerusalén, it became a source for revisions. As Southey declared in the Advertisement to the second edition of Joan, "since the first publication of this Poem, it has undergone a long and laborious correction," perhaps most clearly seen by "the reader who is acquainted with the former edition" in the "numerous" additional notes he had "inserted as authorities for the facts related in the text" $(E P W$ I 199). Lope's Jerusalén featured in many of these new additions chiefly because, as Southey declared, "whenever I have felt, or suspected an idea not to be original, I have placed the passage underneath by which it was suggested" (EPW I 199).

8. Even though the second edition started to take shape in June 1796, with Joseph Cottle already working in an interleaved copy of the quarto for his correction, Southey's revisions, delayed by other commitments, did not really achieve momentum until mid-1797. The final and corrected version was not sent to press until April 1798 (EPW I xxxix). Even though not that much time had elapsed between his reading Jerusalén and the approval of the final corrections, Southey was able to rework several sections of Joan in response to Lope's epic. A case in point shows just 


\section{Romanticism on the Net \#68-69 (Spring-Fall 2017). Special issue on Robert Southey. Guest-edited by Tim Fulford (De Montfort University) and Matthew Sangster (University of Glasgow)}

how closely Southey read Jerusalén and how highly he thought of it. In the first edition of 1796, Southey's portrayal of the close combat between the young Talbot and Joan in Book Ten is characterised by a minute description of how, when both "At once unsheath' $d$ their falchions, and rush'd on / To closer combat" (EPW I 172), Talbot tried in vain to pierce the Maid, whereas she caused him "many a wound" through which she beheld "her foeman's blood / Ooze fast" (EPW I 172). In the 1798 second edition, Southey revised this combat scene in line with a recurrent metaphor in Lope's Jerusalén, and acknowledged so in a footnote: the manner in which Don Juan de Aguila "desata del arçon la espada" [bared the sword from the saddle-bow] (Vega 21) and Ardino's engaging in combat with the "desnudo el rayo de la ardiente espada" [bared lightning of the burning sword] (Vega 444). This metaphor, which Southey had recorded and translated in his Common-Place Book soon after reading Lope's poem, effectively became one of the "corrections" that he introduced in this central scene of Joan. ${ }^{11}$ The defeat of Talbot at the hands of the Maid of Orleans "thro' many a wound" from which "her foeman's blood / Ooze[d] fast" ( $E P W$ I 401) was thus enhanced in 1798 by the powerful Lope-infused imagery of the sword that was to cause those wounds:

He from the saddle bow his falchion caught

Rushing to closer combat, and she bared

The lightning of her sword. (EPW I 401; my emphasis)

While it may be difficult to assess whether the influence of Lope's Jerusalén was stronger in the revisions to the second edition of Joan of Arc or in the shaping of Roderick, Southey's decision to include small corrections of this sort and credit their source in the former bears witness to how seriously he took Lope's work by 1798, and shows how his attitude towards the Spaniard was changed by the process of revising his own epic.

$* * * *$

9. Notwithstanding the significance of Jerusalén for Southey's poetry from 1798 onwards, it is in the 1797 Letters Written During a Short Residence in Spain and Portugal where one can truly appreciate the amount of work Southey conducted on Lope's oeuvre. A commercial success that went into three editions, it represents the formal inception of Southey's interest in all things 


\section{Romanticism on the Net \#68-69 (Spring-Fall 2017). Special issue on Robert Southey. Guest-edited by Tim Fulford (De Montfort University) and Matthew Sangster (University of Glasgow)}

Spanish. On his journey through the Iberian Peninsula, Southey comments on every aspect of Spanish and Portuguese society, from local food and wine, to literature and theatregoing, to the despotism of Iberian politics and Popery. Southey's Letters from Spain and Portugal, however, went beyond the conventions of the travelogue by including almost thirty Spanish (and to a lesser extent Portuguese) poems of considerable length that introduced English readers to two previously neglected literary cultures. ${ }^{12}$ The Letters, as Pratt writes, are indeed "highly characteristic of Southey's work in the 1790s" whilst "provid[ing] an important reminder of Southey's dual relationship to literature," for here he is both "writer and reader, a concerned producer and a highly literate consumer" (EPW V xix-xx). On top of that, the first edition featured two textual supplements crucial to understanding his engagement with Spanish literature in general, and Lope in particular: an "Essay on Spanish and Portuguese Poetry" together with a translation and critical commentary on a central work for the Spanish Golden Age of Baroque literature: Lope's La hermosura de Angélica [The Beauty of Angelica] (1602), an epic conceived as a sequel to Ludovico Ariosto's Orlando furioso [The Frenzy of Orlando] (1532).

10. The essay is particularly interesting for understanding Southey's overall poetics of ambivalence towards Lope, since its whole thesis is grounded on his belief that the despotism of the Catholic Church and the absolutism of Iberian politics were the ultimate causes behind the fact that Spanish — and to a lesser extent Portuguese - poets had never been able to attain such a level of perfection as English ones. Through Southey's own ethnocentrism, his discussion of Spanish literature turns into a treatise on both the political and social history of this Iberian nation, as a well as into discussion of the nature of poetry itself:

To form the real Poet enthusiasm is necessary, and a consciousness of the dignity of his own nature; the one cannot exist in the bigot, and neither of them in the Atheist or in the contented slave of Despotism. Such then are the causes that have combined to prevent the progress of Poetry in Spain,- the licentious negligence of their most favourite authors, the decline of the state, the despotism of the government, and an absurd and abominable superstition. (LSaP 129-30)

As Carol Bolton writes, Southey's irate condemnation of the Catholic Church in Letters from Spain and Portugal stems from a concern about its social impact: "he felt [it] dominated the lives 


\section{Romanticism on the Net \#68-69 (Spring-Fall 2017). Special issue on Robert Southey. Guest-edited by Tim Fulford (De Montfort University) and Matthew Sangster (University of Glasgow)}

of the people to their detriment" (216). Despite Southey eventually growing to be regarded as "the friend of Spain and Spanish literature" (Churton vii), in Letters from Spain and Portugal Southey employs the metaphor of infection, which he would later apply in his accounts of Italy, Ireland, Africa, India, and South America, fearing that contact with foreign cultures could be both physically and morally threatening (see Fulford, "Heroic" 46-64). The disease of Popery, as Southey saw it, thwarted poetic genius. His textual attempts to distance himself from all things Catholic when it came to Spanish literature could thus be seen as an attempt to prevent any sort of contagion from the religious beliefs of Lope. Likewise, hovering over the discussion, in a similar manner as it would haunt the pages of Southey's History of Brazil (1810-1819) and permeate his Letters from England by Don Manuel Alvarez Espriella (1807) (LFE 17), is the "black legend," the inherited story of Spanish rapacity in America that allowed the British to "stereotype the Spanish and the Portuguese as superstitious and cruel" (Fulford, "Araucanians" 227-228).

11. Following a similar line of argument to the essay, Southey's thirty-six-page section on Lope's $L a$ hermosura de Angélica seeks to "make the reader acquainted with the manner, the merits, and the faults of Lope de Vega" who, "confident of his own powers has attempted to rival Tasso in his Jerusalén Conquistada, and Ariosto in The Beauty of Angelica" (LSaP 133). Lope's heroic poem is constructed around Medoro and his lover Angélica, the heroine of Ariosto's epic romance whose beauty led the maddened Orlando, a Christian paladin, to neglect his military duties and pursue her through Europe and into Africa after learning that she had eloped with Medoro, a Saracen knight. Southey meets with nothing but disappointment in his reading of this sequel to the work of Ariosto, finding it to be "lamentably inferior ... in design and execution. ...The Spaniard appears to have begun his poem without knowing how he should conclude it" (LSaP 165). For him, the main reasons why Lope was not able to attain perfection were to be found in the lack of unity of his Angélica, its loose narrative, multiplicity of plots, absence of human feelings, and shallow characterization- "the praise of easy versification [being] all that it deserves" (LSaP 166). Along these lines, Southey concludes his commentary by positing that throughout the whole of Angélica he "do[es] not recollect one solitary touch of Nature," putting forward that it is precisely the knowledge of "human nature and its feelings that forms the Poet; 


\section{Romanticism on the Net \#68-69 (Spring-Fall 2017). Special issue on Robert Southey. Guest-edited by Tim Fulford (De Montfort University) and Matthew Sangster (University of Glasgow)}

without this, he may indeed mould the Promethean statue of Clay, but where is the spirit that shall animate it?" (LSaP 166).

12. Even though, at a surface level, this criticism is constructed upon a genuine analysis of the formal and thematic aspects of Lope's poem; deep within, Southey's commentary is grounded on an anti-Catholic rhetoric not atypical for him, and which he had laid down only some pages earlier in his essay. For Southey, the chief reason behind Lope's failure to fulfil his full potential in Angélica, as in those pieces which, he argued, were "rarely above mediocrity" (CLRS 188), has to do with the fact that, as a Spaniard, Lope's mind had been "fettered by [the] accursed [Spanish] government and [the] accursed hierarchy [of the Inquisition]," the effect of the despotism of Church and State on the mind of the poet being "like that of those poisons on the body that produce death by a slow but certain operation" (LSaP 127-128). In Southey's view, the corrosive effect of religious and political despotism is what had decimated the minds of Lope and other Spanish writers. Nonetheless, Southey admits in his essay, Spanish poets in general, and Lope in particular, are not entirely devoid of merit, since "labouring under so many disadvantages, it is rather to be wondered at that they have done so much, than that they have not accomplished more" (LSaP 130). In a similar light, Southey concludes his commentary of La hermosura de Angélica by asserting that, in contrast to this epic, "in his smaller pieces ... [Lope] is generally tolerable and sometimes excellent," stressing that "though his Pegasus could not accomplish a long journey, he carried his master easily enough on an evening ride" ( $L S a P 167)$.

13. Marked by paradox and contradiction, these remarks seem to constitute yet another attempt by Southey to distance himself from Lope so as to prevent any sort of contagion from the Romish Church. He appears to have had further reasons for this, as his engagement with Lope's Angélica via Ariosto's Orlando can be traced back all the way to his juvenilia, his early works bearing testimony to his lifelong engagement with heroic verse, "that peculiar line of poetry which I have pursued with most ardour" (LCRS I 119). As Pratt outlines (EPWV xiv), by the time he was ten years old Southey had already embarked on a series of poetical projects, one of its most important ones being an imitation in heroic couplets of Ariosto's Orlando furioso. Southey's interest in 


\section{Romanticism on the Net \#68-69 (Spring-Fall 2017). Special issue on Robert Southey. Guest-edited by Tim Fulford (De Montfort University) and Matthew Sangster (University of Glasgow)}

Lope appears to have been enhanced by his discovery that the Spaniard had accomplished a similar poetical project. As he writes at the opening of his translation in the Letters,

What poetical mind has not been fascinated with the magic of Ariosto? This wild and wonderful Author, after leading the reader through forty-six cantos, leaves him to regret that the work is so soon concluded. ... But of all those who have followed the path that led the Italian poet to immortality, Lope de Vega himself is the most celebrated. (LSaP 131-133)

Seen in this light, Southey's work on La hermosura de Angélica for Letters from Spain and Portugal can be regarded as a way for him to partially resume what he had conceived in his juvenilia, turning into English — by translating Lope's sequel-the story of Angelica and her lover Medoro from the point in which Ariosto left it. And yet, as Southey does time and again throughout the Letters, he eventually has to distance himself from Lope's Angélica as well. During his first acquaintance with all things Spanish and Portuguese almost everything positive became overshadowed by his more negative experiences in the Peninsula, with even the landscape being regarded as being rotted to its core by religious and political despotism ( $L S a P$ 59). This tendency resulted not only from Southey's anti-Catholic beliefs, but also from the nagging thoughts that had haunted his mind ever since he left British soil in December 1795 (Speck 63).

14. With hindsight, however, Southey realised that his time spent among Spaniards had not been as horrible as described in the first edition of his Letters. His later revisions indicate that he came to think that his early published judgments of the powers and merits of Spanish and Portuguese literature in general, and of Lope in particular, might have been premature. In a letter to his brother Thomas from early November 1797, barely ten months after the publication of the Letters, Southey informed him that "my Letters are all sold," and discussed arrangements for a second edition (CLRS 269). Its publication was to be delayed until 1799, and while the actual text did not incorporate as many major revisions as would the third and final edition of 1808, Southey was nevertheless careful to omit both the "Essay on Spanish and Portuguese Poetry" and the critical translation and commentary on La hermosura de Angélica. In a letter to Charles Wynn from July 1798, Southey writes how he was "correct[ing] [the Letters] as they go to press, that is after much 


\section{Romanticism on the Net \#68-69 (Spring-Fall 2017). Special issue on Robert Southey. Guest-edited by Tim Fulford (De Montfort University) and Matthew Sangster (University of Glasgow)}

lopping off previously" (CLRS 334), whereas in January 1799 he would provide him with a hotoff-the-press copy, noting that even if it was "perhaps hardly worth sending" given that there were no major alterations, "it is rid of some of the faults of the first" (CLRS 375). Since the main sections he had cut were the essay and commentary on Angélica, along with some anecdotes that friends and relatives had advised him to leave out, there are grounds to argue that he must have realised that his judgments on Spanish letters had been too impulsive. The more he read of Lope, the less critical his attitude towards him became. So much so that in 1807 he would assert that Angélica "contains many spirited passages, and is certainly of all Lope's long poems, that which may be read with most pleasure" (AR 399).

15. Southey's attacks on Lope de Vega often do not develop beyond his dismissing the poetry as being permeated with Catholicism. That being said, there are a number of instances where Southey elaborates on how those aspects of the Catholic doctrine he despised the most, including the veneration of saints and miracles, lie at the core of his criticism. A case in point are his attacks on two pieces by Lope on the life and works of Saint Francisco, "a personage whose history, gloss it as the Romanists may, is one of the most audacious instances of Romish impiety and imposture" ( $Q R$ 44). One of the poems "upon this atrocious legend" particularly angered Southey because of what he regarded as blasphemous and Popish imagery: Christ being represented "stamping himself upon Francisco as upon yielding wax, body upon body, and soul upon soul!" (QR 44). Equally significant is his taking offence at the Fourth Book of Jerusalén, which enacted passages from the Old Testament "in a manner which [Lope] supposed to be sublime and which, beyond a doubt, accorded with his notions of religious poetry" ( $Q R$ 31). These fragments unleashed Southey's wrath to the point that he considered that they "could not be given in English without giving just offence to the wiser and holier feelings of a protestant people" ( $Q R 31)$.

16. Southey's feelings towards the veneration of saints and miracles are nowhere better seen than in his Vindicice Ecclesice Anglicance (1826), where he makes a case for the use of the words "superstition and idolatry" even if these are regarded "as the most offensive words in language to 


\section{Romanticism on the Net \#68-69 (Spring-Fall 2017). Special issue on Robert Southey. Guest-edited by Tim Fulford (De Montfort University) and Matthew Sangster (University of Glasgow)}

the ear of a Roman Catholic." He argues that "the nature of things is not to be altered by altering their names" and that these evils "would cease to prevail if they were represented always in their true light, and known for what they are," emphasizing that "it is because the Church of Rome is an idolatrous and superstitious Church that we have separated from her" (Vindicice 18-19). Southey had found the veneration of saints and their miracles disturbing ever since his first-hand encounters with Iberian Popery in 1795-96. In Letters from Spain and Portugal, he relates how "in England ... I have felt myself inclined to think that the absurdities of Popery may have been exaggerated: but here, in the words of Mary Wollstonecraft, 'the serious folly of Superstition stares every man of sense in the face"" ( $L S a P 72)$. For all his contempt of the veneration of saints and their miracles, Southey did make some concessions. As Stuart Andrews has shown (135140), he accepted the miracles recorded in the New Testament while rejecting the historical accuracy of those described by early Christian authors and those recorded in the Old Testament. And yet, Southey's poetics of ambivalence reaches its peak when he celebrates those poems that, in the light of this anti-Catholic rhetoric, he should apparently despise. In the third edition of his Letters from Spain and Portugal, as part of the "pertinent matter of fact, which my favourite studies enabled me easily to lay hand on [to] ma[k]e the book more respectable than it was" (CLRS 1518), Southey included a whole new letter (X) on the patron saint of Madrid, Saint Isidro, whom he describes as "a good, honest day-labourer, who is indebted for his apotheosis to the fables which others have invented for him, not to any roguery of his own" (LSaP 1808 I 189). Even though it may seem at first that his contempt is still there-for he simply lays the blame on those who ascribed miracles to Saint Isidro-Southey goes on to recount how during Saint Isidro's beatification by Pope Paul V, which had taken place at the King of Spain's entreaty, what is called a Certamen Poetico, a Poetical Contest, was held. Prizes were given by each of the nine Muses, for Poems in his honour of different kinds; and the whole of these Poems were collected and published by Lope de Vega, under the title Justa Poetica, a Poetical Tournament. Lope had an especial devotion to this Saint, and had previously written a Poem containing ten thousand verses upon his life:.. duller verses he never wrote. Two of St. Isidro's miracles amused me in prose, and perhaps they may amuse you in rhyme. (LSaP 1808 I 189-190) 


\section{Romanticism on the Net \#68-69 (Spring-Fall 2017). Special issue on Robert Southey. Guest-edited by Tim Fulford (De Montfort University) and Matthew Sangster (University of Glasgow)}

By turning into verse some of the miracles of the Spanish Catholic saint, Southey conceived he could make amusing what the Phoenix had made dull, a testament to his rivalry with — and thus respect for-the Spaniard. Using Lope's writings as a blueprint, Southey included two poems of his own in the 1808 edition of Letters from Spain and Portugal: "Old Christoval's Advice, And the Reason Why He Gave It" (LSaP 1808 I 191-194) and "The Wedding Night" (LSaP 1808 I 195-198). These had been originally devised in 1798, following Southey's readings of Lope's Isidro (1599) and Justa poética (1620), and his study of the account of the life and works of Saint Isidro in Alonso de Villegas's Flos sanctorum (1775). Southey, however, was not to finish them until January and December 1799 respectively, when they were published in the Morning Post. "Old Christoval's Advice" and "The Wedding Night" were thus finished a bit too late to be included in the 1799 Letters, but they were possibly inspired by its production, which might explain why Southey was to consider these two poems important enough to be worth remembering nine years later for the final edition of his Iberian travelogue. Indeed, Southey never fully abandoned one of these poems, "Old Christoval's Advice," which also saw the light in his 1799 Annual Anthology (AA I 85-89) - a project very dear to him that had a "crucial role in defining the originary locality, language, and concerns of what we now call Romanticism" (Fulford, Coteries 17) - and was later included in the 1837-38 Poetical Works collected by himself (PWCH VI 78-81). ${ }^{13}$

17. "Old Christoval's Advice" is a moral piece in which Christoval, a sixty-seven-year-old farmer, tells how, being in his younger years a poor, bold man without any friends or relatives, and wanting to rent a piece of land from his master Henrique to set up a farm, he asked the latter for money before Saint Isidro's shrine in Saint Andres' Church, petitioning the saint to stand as surety for his payment:

Accept for my surety ST. ISIDRO,

I ventur'd to make reply;

The Saint in heav'n may perhaps be my friend,

But friendless on earth am I. (LPW I 85-86)

If he was not to duly pay his rent, Saint Isidro would make sure that Christoval felt the full weight of his vengeance fall upon him: 


\section{Romanticism on the Net \#68-69 (Spring-Fall 2017). Special issue on Robert Southey. Guest-edited by Tim Fulford (De Montfort University) and Matthew Sangster (University of Glasgow)}

I call upon thee my surety to be,

Thou knowest my honest intent;

And if ever I break my plighted word,

Let thy vengeance make me repent. ( $L P W$ I 86$)$

When the penniless and idle Christoval fails to deliver on his part of the deal, the saint is not vengeful, but responds with genuine compassion. Saint Isidro turns Henrique into a merciful and forgiving master, allowing Christoval to repay his debt only when he has amended his faults and his means allow him to do so. This act of kindness makes Christoval a changed man who "Homeward ... went a penitent, / And ... never was idle more" (LPW I 87).

18. Southey's ambivalence towards Lope de Vega is perhaps nowhere better seen than in this piece. While his detestation of miracles and the veneration of saints lies at the core of his criticism of Lope's poetry, with “Old Christoval's Advice” Southey attempts to rival the Spaniard at his own game, paradoxically engaging with those aspects of the Catholic ethos that he most despises, and which he contends thwart poetic genius. This is even more striking when considering that the account of the miracle in Southey's source material, Villegas's Flos sanctorum (366), does not include many of the details that portray the saint in a positive light. These details are Southey's own additions. For illustration purposes, in Villegas's account the (nameless) farmer, not having any money in store due to his carelessness, and fearing his master's wrath, flees from the village and spends a whole night walking away from it only to find out in the morning that he has been wandering in circles around Saint Andres' Church, where his master is just arriving in order to demand that Saint Isidro executes his vengeance upon him. Villegas's account ends as soon as the farmer "pidió perdon al Santo, y à su amo, al qual satisfizo despues enteramente por su trabajo" [asked the Saint for forgiveness, as well as his master, whom he then fully compensated] (366). By contrast, Southey gives significantly more prominence to Christoval's remorse, emphasizing the importance of praying for the forgiveness of one's sins, and dwelling on the agency that Saint Isidro has in turning both Henrique and Christoval into reformed and goodhearted men:

I shook like a palsy, and fell on my knees, And for pardon devoutly I pray'd: 


\section{Romanticism on the Net \#68-69 (Spring-Fall 2017). Special issue on Robert Southey. Guest-edited by Tim Fulford (De Montfort University) and Matthew Sangster (University of Glasgow)}

When my master came up-what, CHRISTOVAL!

You are here betimes, he said.

I have been idle, good master, I cried,

Good master, and I have been wrong.

And I have been running round the Church

In penance all night long.

If thou hast been idle, HENRIQUE said,

"Go home and thy fault amend.

I will not oppress thee, CHRISTOVAL,

May the Saint thy labours befriend."

Homeward I went a penitent,

And I never was idle more,

ST. ISIDRO blest my industry,

As he punish'd my fault before.

When my debtor was poor, old CHRISTOVAL said,

I have never exacted my due.

I remember'd HENRIQUE was good to me,

And copied his goodness too.

When my neighbour has sinn'd, old CHRISTOVAL said,

I have ever forgiven his sin,

For I thought of the night by ST. ANDRES' church;

And remember'd what I might have been. ( $L P W$ I 87-88)

These stanzas certainly make the poem more amusing than both Lope's dawdling ten-thousandverse piece on Saint Isidro and Villegas's account of this particular miracle, allowing Southey to prove that he is able to make engaging what, in his view, the Phoenix had only made tedious. Yet 


\section{Romanticism on the Net \#68-69 (Spring-Fall 2017). Special issue on Robert Southey. Guest-edited by Tim Fulford (De Montfort University) and Matthew Sangster (University of Glasgow)}

they also offer a view of Catholic penitential practices that is strikingly positive when compared with Southey's anti-Catholic pronouncements elsewhere. One should look no further than the 1797 edition of Letters from Spain and Portugal, where Southey explicitly condemned the Sacrament of Penance and Reconciliation after observing a woman at confession in the Cathedral of Lugo, arguing that much of the depravity of the Spanish,

may be attributed to the nature of their religion: they confess their crimes, wipe off the old score by absolution, and set off with light hearts and clear consciences, to begin a new one. ... This forgiving power vested in the church, will, among the mob of mankind, destroy the motives to virtue, by eradicating all dread of the consequences of vice. $(L S a P 43-45)$

In the Book of the Church in 1824 he would later denounce such practices as leading to actions "instead of being tried by the eternal standard of right and wrong," being "judged by the rules of a pernicious casuistry, the intent of which was to make men satisfied with themselves upon the cheapest terms," with the foreseeable effect of "human laws bec[oming] the only restraint upon evil propensities, when men were taught to believe that the account with Divine Justice might easily be settled" (BotC I 313). This ambivalent stance might be said to epitomise how Southey was "extremely good at saying what he disliked or disapproved of, but ... was on much less certain ground when trying to explain what he approved of or condoned" (Pratt, Contexts xxi).

19. Southey's second poem on Saint Isidro, "The Wedding Night," is an amusing piece wherein a young gentleman by the name of Hernando vows to make an offering upon Saint Isidro's shrine on his wedding day if the saint assists him in gaining the favour of the beautiful Aldonza. Isidro miraculously obliges, but as soon as Hernando and Aldonza's wedding day arrives and they pronounce their mutual marriage oaths, the youth forgets Isidro's aid and neglects his vow. After the wedding banquet, once all the guests "one by one ... drop away" and "the festive hall is emptied quite" (LPW I 161), Hernando is "summon'd to his door / By an old man cloth'd in grey" ( $L P W$ I 162) who bids the bridegroom to follow him, "His voice he felt in ev'ry limb, / And forc'd them to obey" (LPW I 162). This ghostly figure leads Hernando back to Saint Andres' Church, where Saint Isidro teaches him a lesson by making him spend his wedding night standing vigil outside the saint's tomb:

The youth that sacred shrine survey'd, 


\section{Romanticism on the Net \#68-69 (Spring-Fall 2017). Special issue on Robert Southey. Guest-edited by Tim Fulford (De Montfort University) and Matthew Sangster (University of Glasgow)}

And shook to see no corpse was laid

Within that open tomb.

"Learn thou to pay thy debts aright!"

Severe the old man said,

As in the tomb himself he laid,

"Nor more of vows make light."

The yawning marble clos'd its womb,

And left Hernando by the tomb,

To pass his Wedding Night. (LPW I 162)

“The Wedding Night” did not appear in print until December 18, 1799 (EPW V 515-517; Curry 20), whereas “Old Christoval's Advice” had been published on January 7. Nevertheless, there are grounds for believing that Southey came up with the idea for both poems at the same time. In his Common-Place Book, he records jointly the two miracles described by Villegas as furnishing him with the materials to produce a couple of ballads (CP IV 193-194), and shortly after publishing “Old Christoval's Advice" in the Morning Post, Southey tells Charles Wynn in a letter dated February 4, 1799 of a miracle of Saint Isidro having provided him "with a legend which will work up into a somewhat terrific \& grotesque [ballad]" (CLRS 377). This clearly aligns Southey’s interest in Lope and Saint Isidro with his early engagement with the gothic, these poems - or rather, "ballads" (PWCH VI 78-81; CP IV 193-94; CLRS 377)—bearing an uncanny resemblance to the series of gothic ballads he had produced for his 1797 Poems, including "Donica" and "Rudiger" (EPW V 118-128). For these, Southey took as a point of departure the work of Matthew "Monk" Lewis and Gottfried Bürger (Gamer 105). The alignment of these pieces with Southey's early interest in the gothic constitutes but the beginning of a trend that was to be present throughout his career, since Gothicism was to inform virtually all of his writings on the literature and culture of medieval Spain (Duggett, Gothic Romanticism 7).

20. "Old Christoval's Advice" had been preceded by a prose account of the miracle that it related ( $A A$ I 85-89; PWCH VI 78-81). "The Wedding Night," however, never featured such paratext, perhaps because Southey was only loosely taking Villegas's account in the Flos sanctorum as a 


\section{Romanticism on the Net \#68-69 (Spring-Fall 2017). Special issue on Robert Southey. Guest-edited by Tim Fulford (De Montfort University) and Matthew Sangster (University of Glasgow)}

blueprint, introducing major changes to the plot. The version of the miracle recorded in Villegas (367) revolves around Doña Ana María Remesal, a wealthy woman who vowed, on the wedding day of her sister, to give a certain sum of money towards the canonization of the saint if the marriage was to take place according to her desire. It took place exactly as she intended thanks to the grace of Saint Isidro, but in her happiness, she forgot her vow. As soon as she retired to sleep that night, the wife of Saint Isidro appeared before her together with a stern bailiff and a black hound in a chain, who arrested her for her debt only to let her go on the sincere promise of a speedy payment. In his Common-Place Book, we can find Southey altering the story so as to make the poetical piece more appealing. After outlining the basic plot of the miracle, Southey notes:

this will make a tolerable ballad. Let her be called from the company on the wedding evening, and led to the tomb of St. Isidore [sic], to pass the night. It should be the bridegroom who makes the vow. (CP IV 194)

While Southey's poem is rather grotesque, the sanction imposed lasts but one night, and is a rather ludicrous one. He does not portray Isidro as a vengeful saint, but rather as one who makes Hernando learn his lesson by removing him from the side of his beloved Aldonza for less than a day. What is more, in the original account of the miracle that Southey read in Flos sanctorum, the bailiff does release the blood-thirsty hound, who clings to the woman's clothes until she vows to make a speedy payment (Villegas 367). Southey's downplaying of the vindictiveness of Saint Isidro in this respect is clearer in the light of his 1818 piece for the Quarterly Review on the second edition of Lord Holland's Life of Lope de Vega (1817). There he returns yet once again to Lope's engagement with this Saint, once more drawing from Villegas's account of his life and works (367), in broad terms still portraying him as having been "pious" and "charitable." While outlining the most relevant miracles performed by Saint Isidro, and after dealing with the very one that gave rise to "The Wedding Night," Southey moves on to discuss a "similar miracle," which turns out to be the reworked plot he used for his poem, but which Southey nevertheless portrays as if it were an actual account of Saint Isidro's favour:

A cavalier made a similar vow, if by the Saint's favour he might obtain the lady whom he loved; and he promised to make the offering on his wedding-day; - - on the wedding day he was too happy to remember his debt:- before the wedding guests had departed, 


\section{Romanticism on the Net \#68-69 (Spring-Fall 2017). Special issue on Robert Southey. Guest-edited by Tim Fulford (De Montfort University) and Matthew Sangster (University of Glasgow)}

he was called away from the table by an old man whom he had no power to resist, - it was Isidro himself, who led him to the church in which the offering ought to have been made, and, telling the terrified and confounded bridegroom to remember, and discharge his debts, withdrew into his tomb, and left him to pass the night there as pleasantly as he could. ( $Q R$ 34-35)

Southey's discussion of Lope's fascination with the Saint in the Quarterly Review is governed by his contention that the Spaniard used the history of Saint Isidro in an attempt to "succeed ... in narrative poetry" ( $Q R 34)$, a goal that, in the eyes of Southey, he by no means achieved. Seen in this light, the fact that Southey disguises a summary of his own poem as an actual account of Saint Isidro's miracles, and goes so far as to embed it within his piece for the Quarterly, might be read as an instance of literary pride-Southey silently marking as his own the very narrative that Lope had made the basis of his narrative verse.

21. This being said, Southey's relatively considerate and magnanimous saint contrasts with the view that Villegas gave in his Flos sanctorum and which he recorded in the Quarterly Review, which was that in his lifetime no saint could be "more gentle and obliging; [while] after his death he became a severe creditor, and stood upon the point of honour with all the punctiliousness of a newly made grandee" ( $Q R 34)$. Following the uncanny nod to his own poem on the Spanish saint in the Quarterly, Southey goes on to criticise the faults of Lope's Isidro once more, chiefly on the grounds of a lack of "condensation of thought and terseness of expression" ( $Q R$ 36). However, in the span of over two pages he spends commenting on Isidro, there is evidence that he did enjoy this ten-canto poem to a certain extent. A case in point is his declaring that "the early life and occupation of Isidro are prettily described" ( $Q R 36)$, or his putting forward how beautifully Lope portrays the manner in which "the fields, the running waters, and the flowers were [Isidro's] books of divinity" ( $Q R$ 37). It would then be reasonable to conclude that Southey's engagement with Lope's Isidro runs deeper than is indicated by his allusions in the 1808 Letters. While he finds some repulsive and uninspiring things in it, Southey also finds some passages appealing enough to keep investing in Lope's piece and in Saint Isidro as a poetic subject. 


\section{Romanticism on the Net \#68-69 (Spring-Fall 2017). Special issue on Robert Southey. Guest-edited by}

Tim Fulford (De Montfort University) and Matthew Sangster (University of Glasgow)

22. What remains striking, however, is how Southey was willing to go to such lengths on the topic of Saint Isidro as part of his investment in all things Lope despite his well-documented detestation of Catholicism. The matter is a complex one. On the one hand, Andrews's contention that prior to 1802 Southey's "casual” encounters with Catholicism in Portugal, Spain, and Ireland "had not yet crystallized into a concerted attack on the Catholic Church or a coherent defence of Anglicanism" (Andrews 22) might explain why in "Old Christoval's Advice," and to a lesser extent in "The Wedding Night," Southey has no major problems in positively engaging with the devotional practices, structure, and doctrine of Roman Catholicism he would fight so fiercely against in the Quarterly Review between 1811 and 1829. And yet, already in the articles on Spanish and Portuguese poetry that he produced for the Monthly Magazine in 1796, as well as in his 1797 Letters from Spain and Portugal, those same aspects of the Catholic ethos lay at the core of his criticism of Spanish literature in general, and of Lope in particular: "the spirit and the forms of Popery ... as in the doctrine of the Real Presence, the reverence of Relics, and the practice of Confession" were among the "causes that have combined to prevent the progress of Poetry in Spain" (LSaP 129). Lope de Vega and his dangerous abilities had thus "assisted the progress of the evil" ( $L S a P$ 127). What is more, Southey decided to include "Old Christoval's Advice" together with "The Wedding Night" in the third edition of his Letters in 1808 among the additions he introduced "to make a book of which I need not be ashamed" (CLRS 1511), and kept portraying the legend of Saint Isidro in a positive light as late as 1818 in his review of Lord Holland's Life of Lope for the Quarterly. As I see it, these two 1799 pieces, recast in 1808 and defended in 1818, are clearly a statement of Southey's conflicted attempt to rival Lope's poetic genius. As well as testifying to Southey's poetics of ambivalence, the composition and recasting of "Old Christoval's Advice" and "The Wedding Night" could thus be regarded as Southey's own attempt to prove that he would have been a worthy contestant in the poetical contest that Lope recorded in his Justa poética (1620). In 1818, Southey would devote four pages in his piece for the Quarterly Review (37-40) to dwelling in the utmost detail on the dynamics of the poetical tournament, justifying the utter fascination he displays for Lope's Justa poética by claiming that "a festival so characteristic of the age and country deserves to be thus minutely described" ( $Q R$ 39). 


\section{Romanticism on the Net \#68-69 (Spring-Fall 2017). Special issue on Robert Southey. Guest-edited by Tim Fulford (De Montfort University) and Matthew Sangster (University of Glasgow)}

23. His engaging in such a manner with the religious poetry of the Spaniard was not only restricted to his pieces on Saint Isidro, but it was certainly facilitated by these and his extensive readings and re-readings of Lope's poems and plays during the 1810s. In the 1818 article for the Quarterly Review, when Southey was both better read and fonder of Lope than in the late 1790s or in the 1808 edition of the Letters, he argues:

the characteristic merits and faults of this remarkable writer are nowhere more strikingly exemplified than in his Rimas sacras, where he has written sometimes with the utmost extravagance of fancy and perversion of taste; at other times, with a strength of religious feeling which command from the reader something more than approbation. ( $Q R$ 44; my emphasis)

Towards the end of his piece for the Quarterly, Southey is both more zealous and less cautious than in his previous criticism. In doing so he is raising the spectre, in the heyday of the Catholic Emancipation debate, not only of sympathy but of something more than approval for the religious beliefs of the Spaniard; feelings which he had so fervently attacked in this very same piece for the Quarterly —arguing only some pages earlier that Lope's notions of religious poetry "could not be given in English without giving just offence to the wiser and holier feelings of a protestant people" (QR 31).

24. In his discussion of Rimas sacras, Southey goes on to endorse some particular poems that clearly have Catholic implications, most notably a piece on Saint Sebastian, a third-century Christian saint venerated in the Roman Catholic and Orthodox churches, whose martyrdom features prominently in the Book of Psalms. Southey writes how "among the extraordinary compositions in this collection" there was a sonnet on Saint Sebastian, "in which God and man are described shooting at him as at a mark, and he dies by the arrows of divine love before those of human cruelty can reach him" ( $Q R$ 44). Given his recurrent criticism of Lope's treatment of the veneration of saints and medieval miracles, it is significant that Southey chooses this sonnet as an example. Most of the poems in Rimas sacras are written in the first person and addressed to an unnamed interlocutor, a "You" whose implied presence permeates the sonnets with a sense of intimacy and immediacy; a smaller number of the poems included in this collection are hagiographic, liturgical, or commemorative (Pedraza Jiménez 64). One would think that Southey 


\section{Romanticism on the Net \#68-69 (Spring-Fall 2017). Special issue on Robert Southey. Guest-edited by Tim Fulford (De Montfort University) and Matthew Sangster (University of Glasgow)}

would have found a true Christian spirit in the larger group of sonnets rather than in a hagiographic poem on Saint Sebastian. Nevertheless, he goes on describing other pieces he enjoyed from Rimas sacras, including "a sermon of the Archbishop of Toledo's, versified in trinal rhyme in the course of the day in which he heard it delivered," and, even more strikingly, a carol on the sacrament of the Holy Communion that Southey regards as being so remarkable that it is "more fitting to transcribe than to translate" ( $Q R$ 44). Southey's reading of Rimas sacras is perhaps at its most surprising in endorsing this carol, a piece on the sacrament of the Eucharist with an inherent connection with the Catholic doctrine of transubstantiation, a tenet which Southey would portray in his Book of the Church as being grounded on a "proposition no man could believe, unless he disregarded the evidence of his senses" (BotC I 361). Nevertheless, in the Quarterly Review he endorses Lope's carol on the Eucharist as another "extraordinary composition," a poem that "begins by addressing the wafer as a knight in masquerade, and ends in a sort of epigram" ( $Q R$ 44), which directly addresses the doctrine of transubstantiation by employing the Latin phrase "verbum caro factum est," meaning "the word was made into flesh":

Mas siendo verdad que un dia

Verbum caro factum est;

Quien dio su palabra en carne

No es mucho que en Pan se de. (QR 44)

It is ironic that while in his early criticism Southey disregards some of Lope's poems and plays on the grounds of their having deep Catholic imprints, he later readily labels as Christian and "extraordinary compositions" pieces that clearly have a Catholic ethos at their core. In these instances, it seems that, in Southey's eyes, Lope's poetic genius outweighs his abominable superstition, so much so that he is able momentarily to suspend his contempt towards Popery and simply acknowledge the beauty of the Spaniard's verse. This poetics of ambivalence, however, is what lies at the core of Southey's whole career. As Pratt writes, Southey is a writer who resists categorisation, his beliefs, including those on religion, being "surprisingly difficult to map ... perhaps because he was not always that clear about them himself" (Contexts xxi). In fact, whilst this celebration of Lope's oeuvre is followed by a scornful attack on a couple of sonnets on Saint Francisco and Saint Lorenzo, whose "atrocious" legends, in contrast to those of Saint Isidro and Saint Sebastian, Southey believes to be "one of the most audacious instances of Romish impiety 


\section{Romanticism on the Net \#68-69 (Spring-Fall 2017). Special issue on Robert Southey. Guest-edited by Tim Fulford (De Montfort University) and Matthew Sangster (University of Glasgow)}

and imposture" ( $Q R 44)$, he swiftly returns to praise Rimas sacras. Southey thus concludes that despite the despicable pieces mentioned above, there are "strains of sober piety and elevated devotion, in which a true Christian might devoutly join, and bless the man who has expressed for him so well the aspirations of hope and faith" $(Q R 45)$. As he puts it, any true Christian, regardless of the denomination they belong to, can celebrate Rimas sacras.

25. If anti-Catholicism underpinned Southey's readings of Lope in the late 1790s and 1800s, that reading context is far less ferociously evident in 1817 and 1818, being substituted by a Christian one that allows Southey to accept and even welcome both conscious and unconscious religious motifs in Lope's poetry. In his eyes, the writings of the Spaniard are no longer entirely permeated by Popery, but sometimes by a true Christian spirit of which English readers can also partake. This is clearly an attempt on the part of Southey to justify his engaging with these poems, given his previous dismissal of other writings by Lope. In effect, it was only after a twenty-year-long attachment to Lope's poetry that Southey could bring himself to accept some of his religious pieces by focusing on what unites Catholicism and Anglicanism, rather than what separates them.

26. It is particularly remarkable that, for Southey, the best of Lope's writing came from Rimas sacras because this collection appeared the same year in which the Spaniard was ordained a Franciscan priest and appointed Familiar of the Holy Office of the Inquisition (Thacker 25). Southey, however, was not deterred by this. In a letter to Joseph Blanco White of November 1817, he proudly proclaimed that "you will see in the next Quarterly Review that I have translated one or two of Lope de Vega's devotional sonnets,"14 while mistakenly lamenting that "unluckily" he only possesses "the first part of his Rimas sacras, where among many gross absurdities are some of his * most powerful writings" (CLRS 3039). ${ }^{15}$ The Quarterly piece includes several translations, closing with renderings of "Qual delinquante que pasa" [Even as a culprit strives to reach], "Hombre mortal mis padres me engendraron" [My mother bore me mortal; the free sky] and "Yo dormire en el polvo" [I must lie down and slumber in the dust] ( $Q R$ 45-46). The latter, Southey contends,

we conclude the more willingly with ... because we could imagine nothing which would leave upon the reader an impression more favourable to the poet,- or more 


\section{Romanticism on the Net \#68-69 (Spring-Fall 2017). Special issue on Robert Southey. Guest-edited by Tim Fulford (De Montfort University) and Matthew Sangster (University of Glasgow)}

salutary to himself (let us be permitted to add) if he should, in some degree, partake of the feeling with which it has been translated as well as written. ( $Q R 46)$

These concluding remarks illustrate the development of Southey's interest in Lope over a span of over twenty years. The more he read of Lope and the longer he grew accustomed to Spanish culture and literature, the less hostile his attitude became, despite Lope having written so much that seemed unworthy of a great writer and so much that had strong Catholic associations. Southey could never comfortably come to terms with this tension between poetic genius and abominable superstition. However, the fascination endured, as Southey's correspondence and his collecting of numerous volumes of Lope's individual and collected works illustrate. ${ }^{16}$ In this light, even if by 1818 his permanent distrust and detestation of Catholicism still coloured how he saw some of the Spaniard's pieces, Southey's ambivalence eventually gave way, in some instances, to praise for Lope's Catholic oeuvre and to its use as source material for his own verse. This interest in the Spanish playwright — at times political, religious, and literary —epitomises the Southeyan preoccupation with a foreign "Other" that is both fascinating and repulsive, and which, as Pratt points out (Contexts xxvi), characterises much of Southey's writing throughout his career.

27. Southey offers some insightful comments on the role of Spanish — and particularly Lope'spoetry upon his sense of "foreign otherness" in a letter addressed to Chauncy Hare Townshend from April 1818, writing, full of pride, that:

the account of Lope de Vega in the last Quarterly is mine, as you would probably guess. I have read widely in Spanish poetry; and might in historical and literary recollections call myself half a Spaniard, if, being half Portuguese also, this would leave any room for the English part of my intellectual being. (CLRS 3119) 


\section{Romanticism on the Net \#68-69 (Spring-Fall 2017). Special issue on Robert Southey. Guest-edited by Tim Fulford (De Montfort University) and Matthew Sangster (University of Glasgow)}

\section{Works Cited}

Andrews, Stuart. Robert Southey: History, Politics, Religion. New York: Palgrave, 2011.

Bolton, Carol. Writing the Empire: Robert Southey and Romantic Colonialism. London: Pickering \& Chatto, 2007.

Bowers, Will. "The Many Rooms of Holland House.” Re-evaluating the Literary Coterie, 1580-1830. From Sidney to Blackwood's, edited by Will Bowers and Hannah Leah Crummé, New York: Palgrave, 2016, pp. 159-180.

Cervantes, Miguel. Entremeses. Edited by Nicholas Spadaccini. Madrid: Cátedra, 1987.

Churton, Edward. Gongora: An Historical and Critical Essay on the Times of Philip III \& V of Spain. With Translations. London: John Murray, 1862.

Cogan, Richard. Catalogue of the Library in Red Cross Street, Cripplegate; Founded Pursuant to the Will of the Reverend Daniel Williams. 2 vols., London: Richard and John Taylor, 1841.

Curry, Kenneth, editor. The Contributions of Robert Southey to the Morning Post. Tuscaloosa, AL: University of Alabama Press, 1984.

Duggett, Tom. Gothic Romanticism: Architecture, Politics, and Literary Form. New York: Palgrave, 2010.

---. "Southey's 'New System': The Monitorial Controversy and the Making of the 'entire man of letters.'” Romanticism and Victorianism the Net, no. 2012, https://www.erudit.org/en/journals/ravon/2012-n61-ravon0834/1018603ar/.

Flores, Cristina. “'Imported seeds': The Role of William Wordsworth in Miguel de Unamuno’s Poetic Renewal." Romanticism and the Anglo-Hispanic Imaginary, edited by Joselyn M. Almeida, New York: Rodopi, 2010, pp. 249-271.

---. “Contemplative Unamuno: S. T. Coleridge's 'Musings' in Miguel de Unamuno's Poetics." Comparative Critical Studies, vol. 7, no. 1, 2010, pp. 41-65.

---. “William Blake Translated: The Creation of Blake's Literary Fame in Spain.” Comparative Critical Studies, vol. 15, issue supplement, 2018, pp. 117-129.

Fulford, Tim. "Heroic Voyages and Superstitious Natives: Southey’s Imperialist Ideology." Studies in Travel Writing, vol. 2, 1998, pp. 46-64.

---. "British Romantics and Native Americans: The Araucanians of Chile." Studies in Romanticism, vol. 47, no. 2, 2008, pp. 225-252. 


\section{Romanticism on the Net \#68-69 (Spring-Fall 2017). Special issue on Robert Southey. Guest-edited by Tim Fulford (De Montfort University) and Matthew Sangster (University of Glasgow)}

---. Romantic Poetry and Literary Coteries: The Dialect of the Tribe. New York: Palgrave, 2015.

Gamer, Michael. Romanticism and the Gothic: Genre, Reception, and Canon Formation. Cambridge: Cambridge University Press, 2000.

González, Jonathan. "Adaptation and Appropriation: The Afterlife of Samuel Taylor Coleridge in the Spanish Press.” The Coleridge Bulletin, no. 49, 2017, pp. 91-101.

Hayley, William. An Essay on Epic Poetry; In Five Epistles to the Reverend Mr Mason With Notes. London: J. Dodsley, 1782.

Medina Calzada, Sara. “Appropriating Byron's Don Juan: José Joaquín de Mora's Version of the Myth.” Aspects of Byron's Don Juan, edited by Peter Cochran, Newcastle: Cambridge Scholars, 2013, pp. 308-316.

---. "Wars and Heroes: The Romantic Representation of Spain in Don Juan; or The Battle of Tolosa (1816)." Journal of English Studies, vol. 15, 2017, pp. 155-172.

Packer, Ian, and Lynda Pratt. "Robert Southey and the Peninsular Campaign." Spain in British Romanticism 1800-1840, edited by Diego Saglia and Ian Haywood, New York: Palgrave, 2018, pp. 37-54.

Pedraza Jiménez, Felipe. "Las Rimas sacras y su trasfondo." Otro Lope no ha de haber. Edited by M. G. Profeti, Firenze: Alinea Editrice, 2000, pp. 54-83.

Perojo Arronte, María Eugenia. "Imaginative Romanticism and the Search for a Transcendental Art: Coleridge's Poetry and Poetics in Nineteenth-Century Spain." The Reception of S. T. Coleridge in Europe, edited by Elinor Shaffer and Edoardo Zuccato, London: Continuum, 2007, pp. 135166.

---. "Samuel Taylor Coleridge on Don Quixote." Cervantes: Bulletin of the Cervantes Society of America, vol. 34, 2014, pp. 203-218.

---. "Coleridge and Spanish Literature." Spain in British Romanticism 1800-1840, edited by Diego Saglia and Ian Haywood, New York: Palgrave, 2018, pp. 95-114.

Pratt, Lynda, editor. Robert Southey and the Contexts of English Romanticism. Aldershot: Ashgate, 2006. Pratt, Lynda. "What Robert Southey Did Not Write Next." Romanticism, vol. 17, no. 1, 2011, pp. 1-9.

Saglia, Diego. "Nationalist Texts and Counter-Texts: Southey's Roderick and the Dissensions of the Annotated Romance." Nineteenth-Century Literature, vol. 53, 1999, pp. 421-451.

---. Poetic Castles in Spain: British Romanticism and Figurations of Iberia. Amsterdam: Rodopi, 2000. 


\section{Romanticism on the Net \#68-69 (Spring-Fall 2017). Special issue on Robert Southey. Guest-edited by Tim Fulford (De Montfort University) and Matthew Sangster (University of Glasgow)}

---. "Robert Southey's Chronicle of the Cid: Spain as a Textual Archive and Intervention Zone." Cuadernos de Ilustración y Romanticismo, vol. 18, 2002, pp. 39-53.

Saglia, Diego, and Ian Haywood, editors. Spain in British Romanticism 1800-1840. New York: Palgrave, 2018.

Samson, Alexander, and Jonathan Thacker. "Lope's Life and Work." A Companion to Lope de Vega, edited by Alexander Samson and Jonathan Thacker, Woodbridge: Tamesis, 2008, pp. 1-13

Sánchez, Juan L. "Southey, Spain, and Romantic Apostasy." Spain in British Romanticism 1800-1840, edited by Diego Saglia and Ian Haywood, New York: Palgrave, 2018, pp. 55-73.

Sotheby, Leigh. Catalogue of the Valuable Library of the Late Robert Southey, Esq., Ll.d., Poet Laurate. London: Leigh Sotheby \& Co., 1844.

Southey, Robert. The Annual Anthology. 2 vols., Bristol: Longman and Rees, 1799-1800. (AA).

---. The Book of the Church. 2 vols., London: John Murray, 1824. (BotC).

---. The Collected Letters of Robert Southey: A Romantic Circles Electronic Edition. General editors Lynda Pratt, Tim Fulford, and Ian Packer, University of Maryland: Romantic Circles Electronic Editions, 2009-, http://www.rc.umd.edu/editions/southey_letters. (CLRS).

---. Common-Place Book. Edited by John Wood Warter, 4 vols., London: Longman, Brown, Green and Longmans, 1849-1851. (CP).

---. History of Brazil. 3 vols., London: Longman, 1810-1819. (HoB).

---. Journals of a Residence in Portugal 1800-1801 and a Visit to France 1838. Edited by Adolfo Cabral, Oxford: Clarendon, 1960. (Cabral).

---. Later Poetical Works, 1811-1838. Edited by Lynda Pratt, Tim Fulford, Carol Bolton, Ian Packer,

Diego Saglia, Daniel E. White, and Rachel Crawford, 4 vols., London: Pickering \& Chatto, 2012. $(L P W)$.

---. Letters from England by Don Manuel Alvarez Espriella. Edited by Carol Bolton, London and New York: Routledge, 2016. (LFE).

---. Letters Written During a Short Residence in Spain and Portugal. Bristol: Joseph Cottle, 1797. $(L S a P)$.

---. Letters Written During a Journey in Spain, and a Short Residence in Portugal. 2 vols., London: Longman, Hurst, Rees, and Orme, 1808. (LSaP 1808). 


\section{Romanticism on the Net \#68-69 (Spring-Fall 2017). Special issue on Robert Southey. Guest-edited by Tim Fulford (De Montfort University) and Matthew Sangster (University of Glasgow)}

---. The Life and Correspondence of Robert Southey. Edited by Charles Cuthbert Southey, 6 vols., London: Longman, Brown, Green, and Longmans, 1849-50. (LCRS).

---. Poetical Works 1793-1810. Edited by Lynda Pratt, Tim Fulford, and Daniel Sanjiv Roberts, 5 vols., London: Pickering \& Chatto, 2004. (EPW).

---. The Poetical Works of Robert Southey, Collected by Himself. 10 vols., London, Longman, Orme,

Brown, Green, and Longmans, 1837-1838. (PWCH).

[---]. "Some Account of the Lives and Writings of Lope Felix de Vega Carpio, and Guillen de Castro by Henry Richard Lord Holland." Quarterly Review, October 1817 \& May 1818, vol. XVIII, 1818, pp. 1-46. $(Q R)$.

[---]. "Some Account of the Life and Writings of Lope Felix de Vega Carpio by Henry Richard Lord Holland." The Annual Review and History of Literature; for 1806, edited by Arthur Aikin, London: Longman, Hurst, Rees, and Orme, 1807, pp. 397-411. (AR).

---. "To go, and yet to linger on the way." The Poetical Register, and Repository for Fugitive Poetry of 1802, London: F. and C. Rivington, 1803, p. 303.

---. Vindicice Ecclesice Anglicance. Letters to Charles Butler, Esq., Comprising Essays on the Romish Religion, and Vindicating the Book of the Church. London: John Murray, 1826. (Vindicice).

Speck, William Arthur. Robert Southey: Entire Man of Letters. New Haven: Yale University Press, 2006. Thacker, Jonathan. A Companion to Golden Age Theatre. Woodbridge: Tamesis, 2007.

Vega, Lope de. Arcadia. Madrid: Luis Sánchez, 1598.

---. Isidro. Madrid: Luis Sánchez, 1599.

---. La hermosura de Angélica. Barcelona: n.p., 1604.

---. Jerusalén conquistada. Epopeya trágica. Madrid: Juan de la Cuesta, 1609.

---. Rimas sacras. Primera parte. Madrid: Alonso Pérez, 1614.

---. El último godo. Madrid: Viuda de Alonso Martín de Balboa, 1617.

---. Justa poética. Madrid: Alonso Pérez, 1620.

Villegas, Alonso. Flos sanctorum, vida, y hechos de Jesu-Christo, Dios, y señor nuestro, y de todos los santos de que reza, y haze fiesta la Iglesia Catholica. Barcelona: Gibert y Tutó, 1775.

Zarandona, Juan Miguel. "The Amadis of Gaul (1803) and The Chronicle of the Cid (1808) by Robert Southey: The Medieval History of Spain Translated." Charting the Future of Translation History, 


\section{Romanticism on the Net \#68-69 (Spring-Fall 2017). Special issue on Robert Southey. Guest-edited by Tim Fulford (De Montfort University) and Matthew Sangster (University of Glasgow)}

edited by Georges L. Bastin and Paul F. Bandia, Ottawa: University of Ottawa Press, 2008, pp. 309-332.

${ }^{1}$ The author would like to gratefully acknowledge funding from the Spanish Ministry of Economy and Competitiveness through the Research Group BITAE II (FFI2013-47806-R), and from the University of La Rioja and the Research Council of the La Rioja Regional Government through a FPI-UR/CAR scholarship (BOR-A-20170510-III-1137).

${ }^{2}$ On Southey's translations of medieval Spanish literature, see: Juan Miguel Zarandona. “The Amadis of Gaul (1803) and The Chronicle of the Cid (1808) by Robert Southey: The Medieval History of Spain Translated." Charting the Future of Translation History, edited by Georges L. Bastin and Paul F. Bandia, Ottawa: University of Ottawa Press, 2008, pp. 309-332; or Diego Saglia. "Robert Southey’s Chronicle of the Cid: Spain as a Textual Archive and Intervention Zone." Cuadernos de Ilustración y Romanticismo, vol. 18, 2002, pp. 39-53. More recently, articles on Southey's role as one of the bestqualified and most prolific Hispanophile Romantic writers include: Ian Packer and Lynda Pratt. "Robert Southey and the Peninsular Campaign." Spain in British Romanticism 1800-1840, edited by Diego Saglia and Ian Haywood, New York: Palgrave, 2018, pp. 37-54; and Juan L. Sánchez. "Southey, Spain, and Romantic Apostasy." Spain in British Romanticism 1800-1840, edited by Diego Saglia and Ian Haywood, New York: Palgrave, 2018, pp. 55-73.

${ }^{3}$ Southey began conducting extensive research for this piece on August 1817 (CLRS 3015-3016), and he had a final draft ready by November that year (CLRS 3034). His "article upon Lope de Vega" (CLRS 3026) was expected to see the light in the December 1817 issue of the Quarterly Review (Vol. XVII), as Southey proudly declared to friends such as Joseph Blanco White, Charles Wynn, and Charles Bedford (CLRS 3039-3040, 3042). Its publication was nevertheless delayed at the very last minute for the following issue in early 1818 (Vol. XVIII), or, as Southey saw it, "uncivilly shoved aside ... to make room for matters which deserved no such preference" (CLRS 3062).

${ }^{4}$ On the broader context of the reading of Spanish classical literature by, and its impact upon, the Romantics, see, for instance: María Eugenia Perojo Arronte. "Samuel Taylor Coleridge on Don Quixote." Cervantes: Bulletin of the Cervantes Society of America, vol. 34, 2014, pp. 203-218; Sara Medina Calzada. "Wars and Heroes: The Romantic Representation of Spain in Don Juan; or The Battle of Tolosa 


\section{Romanticism on the Net \#68-69 (Spring-Fall 2017). Special issue on Robert Southey. Guest-edited by Tim Fulford (De Montfort University) and Matthew Sangster (University of Glasgow)}

(1816)." Journal of English Studies, vol. 15, 2017, pp. 155-172; or María Eugenia Perojo Arronte. “Coleridge and Spanish Literature." Spain in British Romanticism 1800-1840, edited by Diego Saglia and Ian Haywood, New York: Palgrave, 2018, pp. 95-114. Complimentary to this, Spanish men and women of letters in the late nineteenth and early twentieth centuries developed as much interest for the British Romantics as these had done for Spanish classical writers of the likes of Cervantes and Lope de Vega. For illustrative purposes, see: María Eugenia Perojo Arronte. "Imaginative Romanticism and the Search for a Transcendental Art: Coleridge's Poetry and Poetics in Nineteenth-Century Spain." The Reception of S. T. Coleridge in Europe, edited by Elinor Shaffer and Edoardo Zuccato, London: Continuum, 2007, pp. 135-166; Cristina Flores. "“Imported seeds': The Role of William Wordsworth in Miguel de Unamuno's Poetic Renewal." Romanticism and the Anglo-Hispanic Imaginary, edited by Joselyn M. Almeida, New York: Rodopi, 2010, pp. 249-271; Cristina Flores. “Contemplative Unamuno: S. T. Coleridge's 'Musings' in Miguel de Unamuno's Poetics.” Comparative Critical Studies, vol. 7, no. 1, 2010, pp. 41-65; Sara Medina Calzada. “Appropriating Byron's Don Juan: José Joaquín de Mora’s Version of the Myth." Aspects of Byron's Don Juan, edited by Peter Cochran, Newcastle: Cambridge Scholars, 2013, pp. 308-316; Jonathan González. "Adaptation and Appropriation: The Afterlife of Samuel Taylor Coleridge in the Spanish Press.” The Coleridge Bulletin, no. 49, 2017, pp. 91-101; or, more recently, Cristina Flores. "William Blake Translated: The Creation of Blake's Literary Fame in Spain." Comparative Critical Studies, vol. 15, issue supplement, 2018, pp. 117-129.

${ }^{5}$ On Southey's reconstruction of the Spanish nation in Roderick, The Last of the Goths see: Diego Saglia. Poetic Castles in Spain: British Romanticism and Figurations of Iberia. Amsterdam: Rodopi, 2000, pp. 82-99; Diego Saglia. "Nationalist Texts and Counter-Texts: Southey's Roderick and the Dissensions of the Annotated Romance." Nineteenth-Century Literature, vol. 53, 1999, pp. 421-451; as well as the introduction to Roderick in Southey's Later Poetical Works, 1811-1838 (LPW II: xi-xliii).

6 For "RoberT SoutheY" (Cabral 257).

${ }^{7}$ Southey translated a fragment from Lope's Arcadia as well as his sonnet "Ir y quedarse, y con quedar partirse" [To go, and yet to linger on the way] which, as noted by Pratt (CLRS 188), was to see the light once again some years later, also under the signature "T. Y.," in The Poetical Register, and Repository for Fugitive Poetry of 1802. London: F. and C. Rivington, 1803, p. 303.

8 As the sale catalogue of his library bears witness to (Sotheby 200; no. 3760). 


\section{Romanticism on the Net \#68-69 (Spring-Fall 2017). Special issue on Robert Southey. Guest-edited by Tim Fulford (De Montfort University) and Matthew Sangster (University of Glasgow)}

${ }^{9}$ On the relevance of the library at Holland House for the establishment of this leading cultural and political hub on all things Spanish during the Regency and beyond, see: Will Bowers. "The Many Rooms of Holland House." Re-evaluating the Literary Coterie, 1580-1830. From Sidney to Blackwood's, edited by Will Bowers and Hannah Leah Crummé, New York: Palgrave, 2016, pp. 159-180.

${ }^{10}$ Jerusalén was not the only text by Lope that Southey used as a blueprint for Roderick, having borrowed from Holland House library in September 1813 "two Spanish plays connected with the story of Roderick. I read $<$ thro $>$ both \& made notes from them in the course of the morning" (CLRS 2309). One of these has been identified by Packer and Pratt as Lope's El último godo [The Last of the Goths] (1617), which influenced not only the content but even the subtitle of Southey's poem, the latter bearing an uncanny resemblance to Lope's title.

${ }^{11}$ Southey recorded and translated Lope's line in his Common-Place Book soon after reading Jerusalén: “"Desnudo el rayo de la ardiente espada.' LOPE DE VEGA. 'He bared the lightning of his fiery sword"” (CP IV 271).

12 This ties in with Diego Saglia and Ian Haywood's contention that, in British literature, Spain is to be understood as the creation of Romanticism. As they put it, in contrast to other Continental, Catholic, and "Latin" countries such as Italy and France, which "had been sources of literary inspiration uninterruptedly since the Middle Ages," Spain only emerged on to the literary map, and it did so prominently, in the Romantic period: "it was only at the turn of the nineteenth century that Spanish history, culture, language and literature became the focus of intense interest and study for the British public" (1).

${ }^{13}$ Southey owned original editions of Lope's Isidro (Madrid, 1599), no. 3674 in the sale catalogue of his library (Sotheby 195), and Justa poética (Madrid, 1620), no. 3761 (Sotheby 200), as well as a 1775 reprint of Villegas's Flos sanctorum, no. 3805 in the sale catalogue (Sotheby 203).

${ }^{14}$ Fulford, Packer, and Pratt (CLRS 3039) have identified them as "Sirvio Jacob los siete largos años" [Seven long and tedious years did Jacob serve] and "Quando la Madre antigua reverdeze" [When snows before the genial breath of spring] ( $Q R$ 8-9).

15 In 1614 Lope published this work in Madrid under the title Rimas sacras. Primera parte [Sacred Rhymes. First Part], even though he would never get to complete and publish a second volume. Although he believed he had only read half of it, Southey did read this work in its entirety. 


\section{Romanticism on the Net \#68-69 (Spring-Fall 2017). Special issue on Robert Southey. Guest-edited by Tim Fulford (De Montfort University) and Matthew Sangster (University of Glasgow)}

16 Southey collected some rare editions of La hermosura de Angélica (Barcelona, 1604), Arcadia (Antwerp, 1605), El peregrino en su patria (Madrid, 1618), Rimas sacras (Madrid, 1614), La dorotea (Madrid, 1736), Isidro (Madrid, 1599) - nos. 3670-3674 in the sale catalogue of his library (Sotheby 195) - Jerusalén conquistada (Madrid, 1609), Justa poética (Madrid, 1620), El peregrino en su patria (Madrid, 1733), Colección de las obras sueltas, assi en prosa como en verso (Madrid, 1775), Rimas humanas $y$ divinas (Madrid, 1634) - nos. 3760-3764 in the sale catalogue (Sotheby 200) - Parnaso español. Colección de poesías escogidas de los más célebres poetas castellanos (Madrid, 1768), and El teatro español; o colección de dramas escogidos (London, 1817-1820) - nos. 3644 and 3660 in the sale catalogue (Sotheby 193-194). 